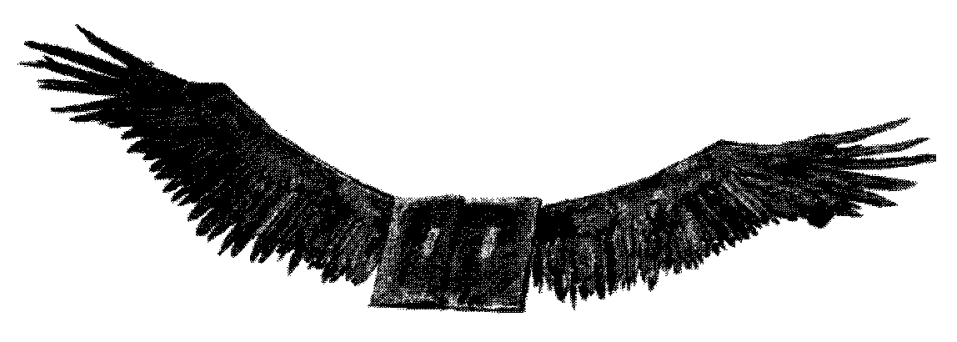

\title{
Reading Matters
}




\section{Narrative in the New Media Ecology}

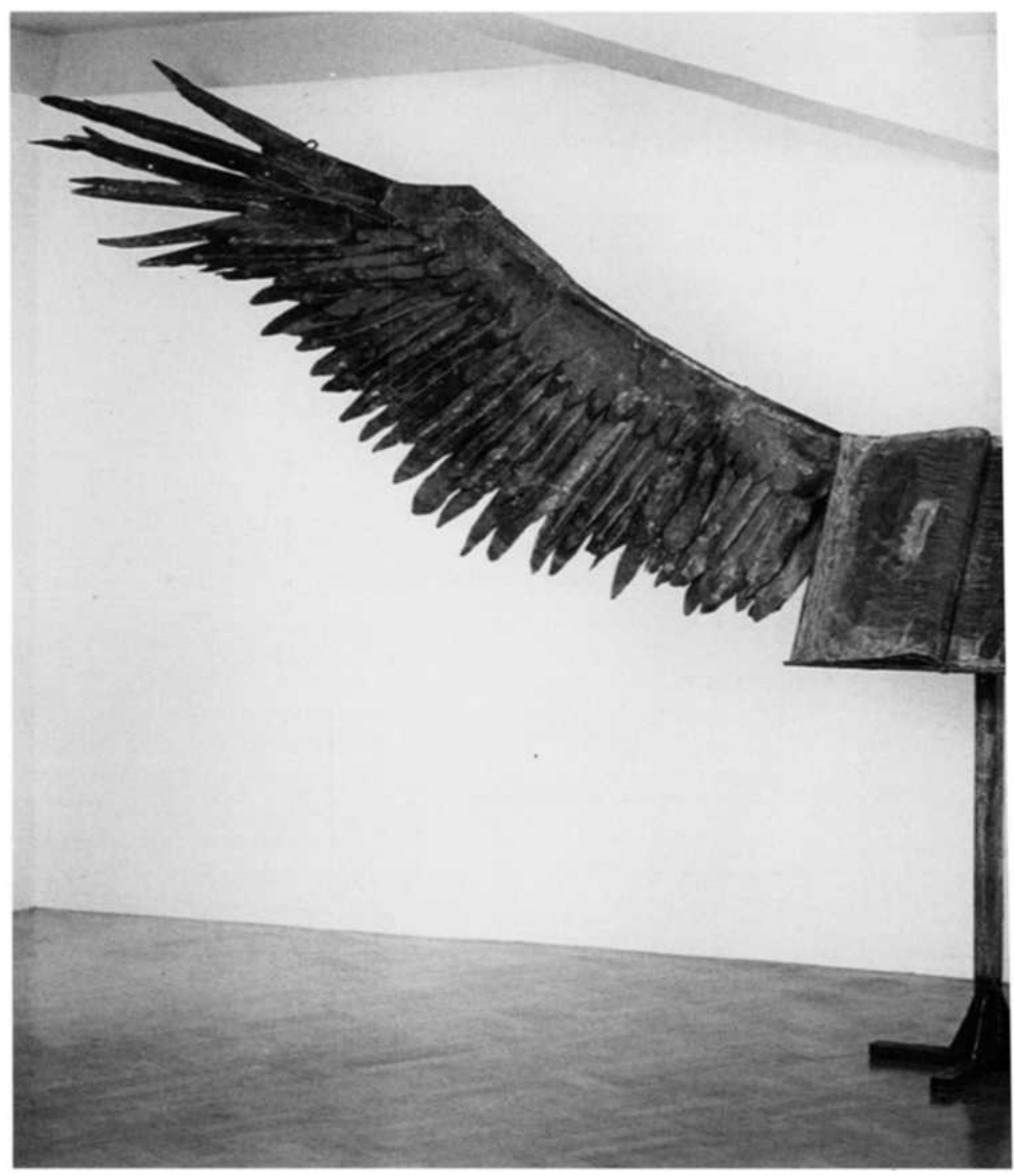




\section{Reading Matters}

Edited by Joseph Tabbi \& Michael Wutz

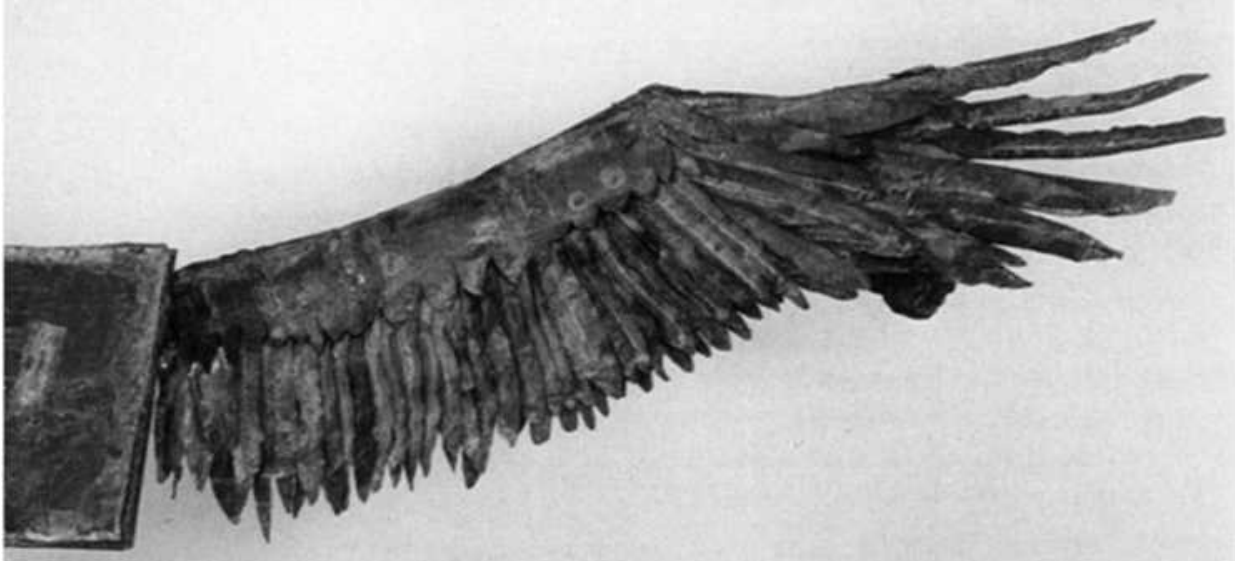

Cornell University Press Ithaca \& London 
Copyright 1997 by Cornell University

"Media and Drugs in Pynchon's Second World War," by Friedrich Kittler, was published as "Medien und Drogen in Pynchons zweitem Weltkrieg," in Die unvollendete Vernunft: Moderne versus Postmoderne, edited by Dietmar Kamper and Willem van Reijen, copyright (C) 1987 by Suhrkamp Verlag, Frankfurt am Main, and is translated here by permission of Suhrkamp Verlag.

Materials from Vineland by Thomas Pynchon, copyright $(\mathcal{C} 1990$ by Thomas Pynchon, are reproduced by permission of Little, Brown and Company.

Materials from Gravity's Rainbow by Thomas Pynchon, copyright (C) 1973 by Thomas Pynchon, are used by permission of Viking Penguin, a division of Penguin Books USA Inc.

Materials from the following works by Malcolm Lowry, copyright (? Malcolm Lowry, are reprinted by permission of Sterling Lord Literistic, Inc.: quotations from The Malcolm Lowry Archive, Special Collections, University of British Columbia; Ultramarine; Under the Volcano; Hear Us $O$ Lord from Heaven Thy Dwelling Place; Dark as the Grave Wherein My Friend Is Laid; October Ferry to Gabriola; Psalms and Songs; Selected Letters of Malcolm Lowry; and Sursum Corda! The Collected Letters of Malcolm Lowry, volume 1: 1926-1946.

Materials from Storming Intrepid by Payne Harrison, copyright (C) 1988 by Payne Harrison, are reprinted by permission of Crown Publishers, Inc.

Materials from Cauldron by Larry Bond and Patrick Larkin are reprinted by permission of Warner Books, Inc, New York, New York, U.S.A. Copyright (O 1993. All rights reserved.

All rights reserved. Except for brief quotations in a review, this book, or parts thereof, must not be reproduced in any form without permission in writing from the publisher. For information, address Cornell University Press, Sage House, 512 East State Street, Ithaca, New York 14850.

First published 1997 by Cornell University Press.

First printing, Cornell Paperbacks, 1997.

Printed in the United States of America

Library of Congress Cataloging-inPublication Data

Reading matters : narrative in the new media ecology / Joseph Tabbi and Michael Wutz, editors.

p. $\mathrm{cm}$.

Includes index.

ISBN (invalid)_o-80I 4-3366-5 (alk. paper).-ISBN 0-8014-8403-o (pbk. : alk. paper)

1. Literature, Modern-2oth centuryHistory and criticism. 2. Postmodernism (Literature) 3. Literature and technology. 4. Narration (Rhetoric)

1. Tabbi, Joseph, 1960- II. Wutz, Michael.

PN771.R45 1997

$809^{\prime} .923$-de21

Cornell University Press strives to utilize environmentally responsible suppliers and materials to the fullest extent possible in the publishing of its books. Such materials include vegetable-based, low-VOC inks and acid-free papers that are also either recycled, totally chlorine-free, or partly composed of nonwood fibers.

Cloth printing $\quad 10987654321$

Paperback printing 10987654321

FRONTISPIECE: Das Buch (The book), 1985, by Anselm Kiefer (Germany, b. 1945). Los Angeles County Museum of Art, Modern and Contemporary Art Council Fund and Louise \& Harold Held. 
Für Josef und Else Wutz,

and for Thomas B. Rohan,

who would have appreciated it 
This page intentionally left blank 